Towards a Critical Political Marketing Agenda?

\author{
Mona Moufahim \\ Nottingham University Business School, \\ Jubilee Campus, Wollaton Road \\ Nottingham NG8 1BB \\ Ph: (0)115-8466659 \\ Email: m.moufahim@nottingham.ac.uk
}

\author{
Ming Lim \\ University of Leicester School of Management \\ Ken Edwards Building \\ University Road \\ Leicester LE1 7RH \\ Ph: (0)116 2523999 \\ Email: m.lim@le.ac.uk
}




\begin{abstract}
This paper conceptualizes political marketing as a field which needs to engage more deeply with the symbolic and discursive insights of critical theory in order to advance significantly beyond its current theoretical and empirical parameters. Although the marketing theories and concepts which have influenced this growing sub-discipline have been applied productively to the marketing of political parties (and, more broadly, to the processes of democratic governance), political marketing scholars now recognize the need to stretch both its theoretical and practical boundaries in order to promote a more inclusive research agenda. This paper reviews some of these concerns, analyses their strengths and weaknesses and proposes a 'critical turn' for the field of political marketing based on critical theories of consumption, production and difference.
\end{abstract}

Keywords: Critical political marketing, marketing theory, critical theories

\author{
About the Authors \\ Mona Moufahim is a Lecturer in Marketing at Nottingham University Business School (NUBS). \\ Her ongoing research is concerned with political marketing, consumption and identity. Her broad \\ research interests include critical marketing, political marketing, and higher education marketing. \\ Jubilee Campus, Wollaton Road, Nottingham NG8 1BB \\ Ph: (0)1158466659 \\ Email: m.moufahim@nottingham.ac.uk \\ Ming Lim is a Lecturer in Critical Marketing and Management at the University of Leicester \\ School of Management (ULSM) where she teaches branding and marketing communications. She \\ has published cross-disciplinary work in the intersections between e-marketing, higher education \\ marketing, business ethics, poststructuralist and literary theory and consumer culture. Her \\ ongoing projects are in branding, creative arts marketing and critical perspectives on political \\ marketing. \\ School of Management \\ Ken Edwards Building, University Road \\ Leicester LE1 7RH \\ Ph: (0)116 2523999 \\ Email:m.lim@le.ac.uk
}




\section{Towards a critical political marketing agenda?}

\section{INTRODUCTION}

The field of "political marketing", although relatively new, has grown quickly over the last few years and now attracts scholars from a number of disciplines outside the mainstream marketing field -- including media and communications, political science and international relations. In recent years, political marketing academics have called for a theoretical and empirical revaluation of political marketing theory and its underlying economic assumptions and ideological components (see for example Savigny, 2008; Wring and Savigny, 2008). This paper seeks to contribute to the debate by considering some limitations of political marketing research and by engaging actively with critical theories and methods which hold promise for future research in this exciting area.

Political marketing may be characterized as the application of marketing concepts to the study of a strategic process involving voters and politicians (and their parties). Henneberg notes, for instance, that political marketers use marketing theory to account for the "strategies and instruments" (2001, p. 94) used by politicians, parties and the political machinery and that, therefore, current political marketing literature has, for the most part, taken an 'instrumental' approach to marketing phenomena, i.e., by focusing on practical, rather than methodological or philosophical, issues, such as election campaigning, polls, and political communications among others (e.g. Lees-Marshment, 2001a and 2001b; 2002; Kotler and Kotler, 1999; O'Cass, 1996; O’Shaughnessy, 1996, 1990; Newman, 1994; Sabato, 1981). Political marketing, as a new subdiscipline, has sought legitimacy for its theoretical basis by borrowing from conventional marketing concepts such as 'marketing orientation' (Narver and Slater, 1990; Kohli and Jaworski, 
1990), the 'exchange characteristics' of the political market (Egan, 1999; Collins and Butler, 2002) or the 'service-dominant' paradigm in marketing (Vargo and Lusch, 2004). As Henneberg and O'Shaughnessy observe, quite rightly, its "historical development out of marketing theory provides the ontological rationale for political marketing” $(2007$, p. 9).

Although we agree in principle with the idea that party politics and its machinations are highly significant in political marketing research because "(p)olitical marketing is about the making and unmaking of governments in a democracy" (O'Shaughnessy and Henneberg, 2001, p. xiv), there are growing concerns among scholars that theories of political marketing are "underimagined", to borrow Brownlie's phrase. In particular, political marketing scholars continue to wrestle with the narrowly pragmatic nature of much of the research conducted by their peers and colleagues. The same scholars who have successfully promulgated 'mainstream' theories of political marketing recognise that the sub-discipline now needs to advance beyond the 'marketing concept' by reexamining its epistemological assumptions, embracing pluralism and multidisciplinarity, and drawing upon alternative marketing theories (Henneberg, 2007; Henneberg and O' Shaughnessy, 2007). However, much work remains to be done to explicate such a vision.

This paper investigates the likely sources and implications of a more critical orientation in political marketing research. In doing so, we hope to map out a vision for the future of political marketing rather than a set of tools or methods as such. The aim is to articulate a political marketing agenda which goes beyond the traditional confines of mainstream marketing and political science for inspiration and growth. That is to say, if we are seeking a more thoughtful agenda for a critical theory of political marketing, then what are some possible intellectual sources we can draw upon? 
The paper is structured as follows. Following this introduction, the second section identifies key strands in the debates between mainstream political marketing literature and emerging ideas on the intersections between business and politics (see Baines and Egan, 2001; Harris, 2001; Butler and Collins, 1994; Niffenegger, 1989). The third section focuses on the foundations (and, by implication, the rationale) for a critical research agenda. In this context, we examine the arguments of 'critical marketing' (Saren et al., 2007; Brownlie, 2006; Brownlie et al, 1999; Morgan, 1992; Brownlie and Saren, 1995) which are not only salient to, but underexplored in, in political marketing research. In Section Four, we identify a range of critical social theories (including theories of production and consumption and the Critical Theory of the Frankfurt School) which have not, to date, been comprehensively included in the political marketing domain. This section explains their relevance and their applicability of various critical theories to political phenomena and alludes to the way in which such an agenda changes both the tone and content of the political marketing agenda. Finally, we discuss the implications of a critical approach to political marketing and conclude with future directions for research.

\section{THE NATURE OF POLITICAL MARKETING: CURRENT DEBATES}

According to Wring (1997), the term 'political marketing' was first coined by Kelley (1956) in his study on the increasing influence of professional persuaders in politics. For Kelley (1956), 'marketing' essentially meant 'persuasion' and was an update of a theme familiar since the First World War, as a new instrument of social control. However, the use of the marketing discourse also reflects the view that professionals from the commercial marketing industry, especially marketing, were increasingly involved in political persuasion (Scammell, 1999). 
The gradual, but inexorable, intrusion of a corporate mindset into political marketing is hardly new, but is only now being critically acknowledged as a source of conceptual 'contamination' by scholars. In this sense, political marketing resembles what Kotler and Andreassen (1991, p. 42) have called the "mindset of consumer-centeredness" (in O'Cass, 1996) inside the organisation. The many analogies between consumer marketing and political marketing have clearly been exploited by researchers (see among others Egan, 1999; O’Cass, 1996; Niffenegger, 1989; O’Leary and Iredale, 1976; Kotler, 1975; Shama, 1973). Applied to political processes, commercial marketing becomes 'political marketing', i.e. the application of business practices to politics and the mindset of 'voter-centredness'. Lees-Marshment (2001) adopts a similar view by arguing that political marketing is about political organisations adapting business-marketing concepts and techniques. Harris (2003) notes the adoption of electoral campaigning techniques in business, for influencing and gaining strategic corporate advantage. Similarly, Andrew (1996) notes the direct relevance of political marketing techniques to business lobbying. As such, lobbying -- already an established tool of modern political communication -- and campaigning by pressure groups are viewed as part of modern marketing (Harris and Lock, 2001; Harris, 2003). Over the last decade and more, analyses of pressure group and political lobbying, public affairs and public relations (e.g. Andrew, 1996; Harris and Lock, 2001; Harris, 2003) have risen to the top of the political marketing research agenda; as such, they form an integral part of contemporary agendas for political marketing research and will be discussed in more detail later in the paper.

At the same time, there are many dissident voices in the debate of the 'appropriateness' of marketing in politics. O'Shaughnessy (2001) considers political marketing and commercial marketing as separate "ecologies" (p. 1057). He argues that marketing is primarily a business discipline and, as such, warns against making the assumption that "political contexts are 
invariably analogous to business to the extent that methods can be important and used with equal effect" (O'Shaughnessy, 2001, p. 1047). Similarly, Lock and Harris argue that the parallels between political marketing and mainstream marketing are superficial, even though "marketing perspectives and analytical methods clearly have considerable applicability" (Lock and Harris, 1996, p. 23) and consequently political marketing, as a separate discipline, needs to develop its own paradigms and vocabulary (Lock and Harris, 1996). Savigny (2008, p.5) even argues that on an idealistic level marketing and politics are actually mutually exclusive categories and therefore both ontologically and analytically distinct. She does, however, acknowledge that on a more practical level this needs to be reconciled with our neoliberal contemporary politics which privileges markets and, more specifically, the practicalities of election campaigning in a technologically dense, media-centred environment (Savigny, 2008).

The debates outlined in this section point towards a more radical edge in political marketing research which is emerging today. We wish to extend the vision much further by drawing attention to critical theories which have been used by scholars in a number of other disciplines as well as empirical methods which highlight the discursive and symbolic realities of 'political' phenomena (see for example Weaver et al., 2004). Weaver et al. (2004, 2006) for example, use critical theory to show how propaganda and public relations can be understood as discourse practices utilised to legitimate social, political and/or economic power and the public interest. For political marketing to mature as a truly interdisciplinary subject (e.g., Hunt, 1983), we advocate not only the application of marketing tools and concepts to politics, but also a deeper engagement with a comprehensive range of social theories which illuminate post-industrial consumer societies. The willingness and ability of scholars and practitioners to develop such an engagement is vital to a 'critical' research agenda for political marketing. 


\section{CRITICAL AND POLITICAL MARKETING: FRAMING THE ISSUES}

The arguments of 'critical marketing' (Bradshaw and Firat, 2008; Tadajewski and Brownlie, 2008; Saren et al., 2007; Brownlie, 2006; Brownlie et al, 1999; Morgan, 1992; Brownlie and Saren, 1995) relate directly to the need to re-examine the conventional assumptions of marketing theory and practice which underpin political marketing research today. Two key implications of critical marketing stand out for our analysis of political marketing research. The first pertains to the ideological construction of the 'market' and 'consumer' as discourses which must be critically examined rather than assumed as 'natural,' let alone desirable, for consumers. The second relates to how political marketing, therefore, constructs citizens and concerned individuals -- in monolithic ways -- as consumers of products and services, thus encouraging party-voter relationships which are commodified along the lines of the market; these, in turn, distort the genuine needs and aspirations of voters.

Political marketing research, therefore, needs to take into account the real effects of these discursive and ideological operations. There is much more scope within the field for greater recognition of the fact that political phenomena is discursively embedded within political and economic systems, through old and new media and new formats of marketing and communications. Emerging research in political marketing (Kaid, 2004; Roper, 2005), for instance, shows how critical marketing can be put to work in empirical analyses of political advertising and communications. The powerful campaign that carried Barack Obama to the White House in 2009 will be remembered for its use of technologies such as Twitter, viral blogs, SMS, social networking sites, all of which were mobilised along with more traditional activist programmes such as volunteering, political advertising and so on. Such research would be grounded in the view that political marketing is the marketing of texts as much as they are about the infrastructure humans construct to interpret and manipulate those texts. 
In terms of how voters are constructed as consumers, a critical politics would need to acknowledge that these communicative platforms tread complex lines of race, ethnicity, gender and class. These differences cannot, and should not, be obliterated through one-dimensional constructions of the voter as a 'consumer'. We note that an ideology of marketing, embodied in marketing discourse, has contributed to the current centrality of consumption in creating meaning and significance in people's lives (Gibson et al., 2003; Brownlie and Horne, 1999). Critical marketing research recognises that marketers not only help provide for the physical needs of consumers; they also provide the symbolic material for their identity construction and expression. As such, marketing has shaped and continues to shape the social sphere by defining the space within which social relations are constituted as social exchanges. A discourse of political marketing which constructs voters not as active citizens in civic society but as consumers deciding which policies and politicians they will 'buy' with their vote must, therefore, be reflexively examined.

Taking all these arguments as a whole, it seems only logical to argue that scholars of political marketing demonstrate greater awareness of our own, self-legitimating, discourses. Political marketing research has largely ignored, or taken for granted, its own ideological bases. A reflexive introspection would provide an alternative position to the largely accepted idea that political marketing is (a self-proclaimed) democracy enhancer (see Kotler and Kotler, 1999). A good starting point would be, for example, to recognise the reflexive power of the marketing discourse itself in perpetuating inequitable relations between voters and institutional forces, between groups of individuals and between governments with widely divergent, yet interconnected, agendas. 


\section{WHAT WOULD A CRITICAL POLITICAL MARKETING AGENDA LOOK LIKE?}

The critical marketing project does not draw attention towards 'new' marketing phenomena, but to the conditions of possibility of the 'new': how we might render different images of what we have already decided is knowable. In this regard, critical marketing argues for a socially and historically located understanding of the discipline and the traditions that link the interpreter with what is interpreted (Arnold and Fischer, 1994; Holbrook, 1997; Brownlie, 2000; Burton, 2001, 2005; Brownlie, 2006). For example, critical political marketing should be sceptical towards associated truth claims, and express doubts about normalising precepts which are taken for granted: such as the problems and consequences of conceiving political marketing management and practice as politically neutral. Together with a need to question the dominance of positivism which continues to inform so much empirical work undertaken in political marketing, we also question rational choice theory and neoclassical economic assumptions underlying political marketing theory (see Savigny, 2008, 2006). Critical political marketing should open up the range of acceptable, possible methodologies, and address a larger range of problems.

In contrast to current conceptualizations of political marketing at present, we propose a conceptual framework to put different, sometimes interlinked, bodies of literature to work. In so doing, we aim to highlight the ways in which political marketing concepts and theories can be tested, undermined and/or strengthened, even simultaneously.

We begin by calling for poststructuralist principles which emphasize the multidimensionality of political phenomena across multiple times and spaces (see Haraway, 1997; Appadurai, 1988; Anderson, 1991; Laclau and Mouffe, 2001) to be more actively embraced by political marketing researchers. These views are sceptical of conventional or 'standard' descriptions of countries, governments, peoples and policies. Let us consider just two examples of how such theories can 
infuse our framing of political phenomena. The first one relates to characterizations of political segments, voter groups and 'special interests' in the political process. In the political marketing literature, these descriptions tend to be static and essentialist. Too often, political marketing research relies on what -- to borrow a phrase from the social geographer, Karen Ettlinger -- calls “concise summations of, for example, "woman", "African American," "homosexual," and so on" (2004, p. 30) instead of probing the layers of how the political process itself produces and sustains ethnic, sexual and national differences and conflicts. The 'rational man' or 'rational voter' is another construct which lends itself to this kind of revisionism.

Another example which can be cited in this context, relates to the party-voter relationship. The analysis of this relationship has been dominated up till now in the literature by instrumental modes: strategies, tactics, advertising. Yet, the symbolic dimension which underlies material representations of this relationship has not been explored in any great depth. We argue that political marketing research should advance beyond the marketing concept in 'traditional' marketing by drawing upon a more nuanced understanding of critical accounts of 'consumer consciousness' (Hirschmann and Holbrook, 1982; Gabriel and Lang, 1995) which shifts between sites of experience and identities. In a globally interconnected economy, political theatre is made within days or even minutes of poll results, campaign trails and policy announcements or even radio, T.V. and Internet advertisements. Underlying these processes, as sociologists and cultural researchers know well, are the politics of consumption, and audience reception of cultural artifacts (see Axford and Huggins, 2002; Kellner, 1989 and 1995).

This particular aspect of critical social theory is profoundly important to political marketing. The commercial forces, which drive what Horkheimer and Adorno (1948/1972) called the "culture industry," found critical expression in the research of the Frankfurt School in the 1930s. A 
comprehensive account of their many complex writings lies outside the scope of this paper, but Adorno's critique of mass television, music, film and political speeches (1991, 1994), Herzog's discussion of radio programmes (1941), Lowenthal's studies of popular culture (1961) provide ample evidence of how all these agents mediate political reality for millions in Europe. Their aim was "to explore and articulate ways in which conditions of social, economic and political domination limit, distort and depreciate discourse regarding contested public issues" (McClure, 1996, p. 488). On a global scale, Critical Theory led the way for a politics of human enlightenment and emancipation so that all (especially minority and vulnerable) interests may be mobilised against elites whose intentions were often kept hidden from those whose lives they affected. For many of the leading lights of Critical Theory, politics was a realm precisely where ordinary men and women would be bewildered and disenfranchised by populist politics, even -or especially -- in so-called 'democratic' societies. Marcuse (1964), for instance, recognised that human reality (the economic, material and cultural operations of life) could easily be operationalised as a political function and thus be made the subject of arbitrary laws of the market, the economy and so on. Thus, the very structures for which we depend on to serve us only install and embed irrationality and the inherent resistance of societies to effect change by rational means.

The political realities of our times demand the kind of trenchant critique by disenfranchised voters which the rhetoric and instruments of Critical Theory strongly suggest (the recent U.S. election is one of the most gripping examples of our time, for example), and yet political marketing researchers have yet to exploit this conceptual possibility in any great depth. As political marketers wrestle with identifying the issues and solutions which characterize so-called 'democratic' societies, we contend that the structural parameters and constraints of the "public sphere" (Habermas, 1989) become even more integral to our understanding of the emancipatory 
projects which engage politicians, voters, backbenchers, frontbenchers, policymakers and media professionals across the political spectrum.

Further, Critical Theory is invaluable in helping researchers discover and unmask the positionings and power relations between and within groups which influence voting outcomes. Rather than fixing on one or two trajectories in a political campaign, we can feature a more dynamic analysis between people and their nodes of influence to take into account symbolic and discursive representations of thoughts, emotions, and other media not just between people but also between people and texts (see Fineman, 2000; Law and Hassard, 1999). The textuality of political institutions and actors are to be understood as both material and immaterial.

To take the argument further, we need to radicalize the content of political marketing itself (see Henneberg, 2007), but not simply in terms of its 'scope' or coverage. 'Political' phenomena, in fact, is a problematic category which needs a stronger exegesis and grounding in contemporary accounts of 'culture' and 'identity', particularly in helping us push the envelope of the subdiscipline further in the direction of cultural economy and the different constructions of 'politics' in different spheres of civil society (du Gay et al., 1996; du Gay, 2007; Hall and du Gay, 1996). A key point of relevance for political marketing scholarship in these kinds of explorations is the ways in which persons and personalities (behind the podium, at a convention, rally or conference, in front of supporters and so on) are constituted out of prior regimes of behaviour and social patterning (du Gay, 2007).

Yet another critical approach is the discursive method, as applied in the marketing literature to understand identity and power relations in advertising (see Elliott and Ritson, 1997; Elliott, 1996). The range of methods which fall under this school of conceptual exploration can be 
applied in critical and political fields to understand political disputes and political rhetoric (e.g. Schön and Rein, 1994). A critically-oriented political marketing research agenda needs methods/methodologies which recognise and manage the ideological nature of texts and discourses. Critical discourse analysis (see Fairclough, 1989; Fairclough and Wodak, 1997; Jäger, 2001; Wodak et al., 1999; Titscher et al., 2000; Wodak, 2001), for example, could provide the tools to approach the issue of power relations between and within groups which influence voting outcomes. For the purposes of political marketing research, critical discourse analysis can be used to analyse 'exogenous' phenomenon in politics (e.g. election campaigns; party behaviour; communication material; media appearances, etc), but could also be used 'internally' to critically analyse the knowledge claims of political marketing literature.

An emancipatory critical political marketing project should seek to determine alternative models of political representation and participation which would be more in line with democratic ideals. Savigny (2008) uses this point, in fact, to address one of the main criticisms against political marketing. The systems of texts through which such models are mediated and expressed thus become critical for political marketing research. Critical discourse analytical methodology, therefore, becomes a powerful tool for addressing the challenges attached to the analysis of complex, potentially polemical and contested discourses, such as the discursive construction of national identities (e.g. de Cillia et al., 1999; Wodak et al., 1999); race relations (e.g. Richardson, 2008; Teo, 2000), extreme-right politics (e.g. Moufahim et al., 2007; Martin-Rojo and van Dijk, 1997), war and peace-keeping (e.g. Ferrari, 2007; Graham et al, 2004); policy debate and financial regulation (Gallhofer et al., 2001); campaigning tactics and positioning (Roper, 2005). A critical approach proved invaluable to Weaver, Motion, and Roper in their analysis of propaganda and public relations (see Weaver et al., 2006). Both propaganda and public relations were framed as (self-) legitimating discourse practices furthering specific interests. Drawing on 
the work of Habermas, Foucault and Fairclough, the authors analysed public relations' discourse (along with the embedded notions of truth, power, and knowledge), and the engineering of public opinion and social action (Weaver et al, 2006). They questioned the accepted idea that propaganda necessarily operates against the public interest, and that public relations necessarily works for the public interest (Weaver et al., 2006, p. 23; original emphasis). They showed otherwise:

[...] discourse theory helps to move away from the notion of propaganda as deception and lying because it acknowledges the potential for competing truths in society: multiple discourses circulate and compete with each other for hegemonic power and therefore there is a choice of meanings, identities and realities available to audiences, not one allpowerful construction of reality (Weaver et al., 2004, p. 23).

This a similar approach that we are championing for approaching and understanding political marketing discourse and practice, in our so-called critical political marketing agenda.

\section{DISCUSSION AND CONCLUSIONS}

We began the paper by identifying the key issues which exercise political marketing scholars in terms of the field's continuing theoretical and empirical development. In their search to establish the ontological and epistemological assumptions of political marketing and to carve out a distinct and attractive disciplinary space for it, political marketing scholars have already demonstrated a healthy scepticism towards its development thus far and a willingness to consider further theoretical developments in the field. Our paper argues that a range of critical theories which have opened up debates in other fields can further drive the political marketing research agenda. Critical marketing viewpoints were taken in this paper, which provide an approach to the study of 
marketing in a political context focusing on ideological formations borne out of the rigorous scrutiny of bourgeois culture and revolutionary movements (Habermas, 1989) as well as the critique of academic discourses. If we accept that ideas in relation to marketing are part of a broader discourse -- the discourse of neoliberalism, for instance, makes the ideas and language of marketing acceptable, rendering them intelligible (Savigny, 2008, p. 74) - then political marketing, too, needs to avail itself of a much greater range of ideas than it has hitherto done.

If political marketing is understood as an instrument that frames and legitimates political discourse in the eyes of voters, then we need new epistemological tools to capture the mechanisms of such legitimation beyond an analysis of instruments, tactics, branding or even linguistically-based methods. Instead, political marketing research needs to take into account more polemical and activist discourses in other fields, as we have shown. For instance, political marketing researchers take for granted that the ability to connect with voters is a key issue for political parties and that marketing discourse is mainly used strategically by parties to make their speeches 'voter-friendly' and encourage the consumption of their political 'product'. Yet, how much do we know about the conditions which make such strategies possible and desirable in the first place? What are the tools which allow such discoveries to be made? Is marketing used as a form of legitimating discourse to make politics accessible to people who have been socialised in a consumer society or is it a way of manufacturing 'consensus' in the public sphere? What are the various 'spheres' 'out there' and who or what do they exclude or silence? By incorporating our proposed research agenda, new kinds of questions can be raised in political marketing and tackled.

Raising these questions throws the spotlight on the field in a new, perhaps uncomfortable, light. Political marketing makes normative-sounding claims that it is 'good', i.e. a convincing self- 
proclamation to be a democracy enhancer ${ }^{1}$ (see Kotler and Kotler, 1999). In saying this, we have also noted, as researchers in the field ourselves, that political marketing scholars are certainly not wrong to defend the sub-discipline and to advocate the application of a marketing orientation to the conduct of politics. What we do can certainly contribute to a better representation of constituents (Savigny, 2004) provided we are more critically aware of their changing and multiple identities, their changing aspirations and the increasing corporatization and globalization of consumers (noting that stable definitions of any or all such groups must remain a provisional exercise at all times).

In conclusion, political marketing has the potential to emerge as an interdisciplinary subject which would inform not only the application of marketing tools and concepts to politics but also the legacy of social theory that informs the study of post-industrial consumer societies today. To do so is to embark upon a rewarding, albeit risky, journey. It is still the case, as Morgan argues, that "marketing is a substantial and powerful discourse which is currently dominated by a highly positivistic and normative approach to knowledge" (1992, p. 154). Political marketing seems to be no exception.

Understanding political marketing as $a$ discourse and opening it up to critical theories of society offers what we believe is a powerful agenda. Integrating the two levels of analysis presents the next challenge for researchers. Future research and thought in this area is needed to lay out the specific problems and avenues for such a project. A synthesis of relevant theories relating to class, gender, sexuality, cultural and socio-economic preferences, for instance, has yet to be attempted and it is hoped that our paper plays a role in the emergence of such a project among different networks of political marketing researchers and academics. Given the plethora of

\footnotetext{
1 By providing the consumer with a product they want, the political process is presented as responsive to consumer demand, which in turn is assumed to make politicians more accountable (Savigny, 2004: 33)
} 
theories and values circulating around common constructs like the 'consumer', the 'voter' and, on a much broader scale, 'society', 'identity' and 'politics' itself, an agenda which maps out diverse framings of these concepts within the field of political marketing can only be a healthy development for the field. Most importantly perhaps, a critical political marketing project should not, in our opinion, exclude a necessary dose of irreverence, polemic, and rejuvenation to allow an enrichment of the discipline's theoretical basis, or indeed, a questioning spirit which can always raise the tantalising question with which we began: 'Towards a Critical Marketing Agenda?' 


\section{Bibliography}

Appadurai, A. (1988) "Introduction: Commodities and the politics of value", in Appadurai, A. (ed.), The Social Life of Things, Cambridge: Cambridge University Press.

Anderson, B. (1991) Imagined Communities: Reflections on the Origin and Spread of Nationalism, London: Verso.

Andrew, L. (1996), "The relationship of political marketing to political lobbying. An examination of the Devonport campaign for the Trident refitting contract”, European Journal of Marketing, Vol. 30, No 10/11, pp. 76-99

Arnold, M. and Fischer, J. (1996) “Counterculture, criticisms, and crisis: assessing the effect of the sixties on marketing thought", Journal of Macromarketing, Spring, pp. 118-199.

Axford, B. and Huggins, R. (2002) "Political marketing and the aestheticisation of politics: Modern politics and postmodern trends", in O'Shaughnessy, N. and Henneberg, S.C.M. (eds.) The Idea of Political Marketing, Westport, CT and London: Praeger, pp. 187-208.

Baines, P.R., and Egan, J. (2001) "Marketing and political campaigning: Mutually exclusive or exclusively mutual?", Qualitative Market Research: An International Journal, Vol.4, No. 1, pp. $25-34$.

Bradshaw, A. and Firat, A.F. (2007) "Rethinking critical marketing”, in Saren, M. Maclaran, P., Goulding, C., Elliott, R. Shankar, A. and Catterall, M. (eds), Critical Marketing: Defining the field. Oxford: Elsevier, pp. 30-43. 
Brownlie, D. (2000) "Interpretation as composition: Debating modes of representation in marketing research, in Beckman, S. and Elliott, R. (eds.), Interpretive Consumer Research, Copenhagen: Copenhagen Business School Press, pp. 47-86.

Brownlie, D. (2006) "Emancipation, epiphany and resistance: On the underimagined and overdetermined in critical marketing”, Journal of Marketing Management, Vol. 22, pp. 505-528.

Brownlie, D. and Saren, M., (1995) "On the commodification of marketing knowledge: Opening themes", Journal of Marketing Management, Vol. 11, Issue 7, pp. 619-628.

Brownlie, D., Saren, M., Wensley, R. and Whittington, R. (eds.) (1999) Rethinking Marketing. Towards Critical Marketing Accountings, London: Sage.

Burton, D. (2001) “Critical marketing theory: The blueprint?”, European Journal of Marketing, Vol. 35, Nos. 5/6, pp. 722-743.

Burton, D. (2005) "Marketing theory matters", British Journal of Management, Vol. 16, No. 1, pp. 5-13.

Butler, P. and Collins, N. (1994) Political Marketing: Structure and Process", European Journal of Marketing, Vol.28, No.1, pp. 19-34.

Du Gay, P. (2007) Organizing Identity: Persons and Organisations after Theory, London: Sage. 
Du Gay, P. Hall, S. Janes, L. Mackay, H. and Negus, K. (1996) Doing Cultural Studies: The Story of the Sony Walkman, London: Sage.

De Cillia, R., Reisigl, M. and Wodak, R. (1999) "The discursive construction of national identities", Discourse \& Society, Vol.10, No. 2, pp. 149-173.

Egan, J. (1999) "Political marketing: Lessons from the mainstream", Journal of Marketing Management, Vol. 15, pp. 495-503.

Elliott, R. and Ritson, M. (1997) "Post-structuralism and the dialectics of advertising: Discourse, ideology, resistance", in Brown, S. and Turley, D. (eds.) (1997), Consumer Research. Postcards from the Edge. London: Routledge.

Elliott, R. (1996) "Discourse analysis: Exploring action, function and conflict in social texts", Marketing Intelligence \& Planning, Vol. 14, Issue 6, pp. 65-68.

Ettlinger, N. (2004) "Toward a critical theory of untidy geographies: The spatiality of emotions in production and consumption", Feminist Economics, Vol. 10, No. 3, pp. 21-54.

Fairclough, N. and Wodak, R. (1997) Critical Discourse Analysis, in van Dijk, T.A. (ed). Discourse as Social Interaction: Volume 1. London: Sage, pp. 253-258.

Fairclough, N. (1989) Language and Power. New York: Longman.

Fairclough, N. (1992) Discourse and Social Change. Cambridge, UK: Polity Press. 
Ferrari, F. (2007) "Metaphor at work in the analysis of political discourse: investigating a 'preventive war' persuasion strategy”, Discourse and Society, Vol.18, pp. 603-625.

Fineman, S. (2000) Emotions in Organizations, Newbury Park, CA: Sage.

Gabriel, Y. and Lang, T. (1995) The Unmanageable Consumer: Contemporary Consumption and its Fragmentation", London: Sage.

Gallhofer, S., Haslam, J. and Roper, J. (2001) “Applying Critical Discourse Analysis: Struggles over Takeovers Legislation in New Zealand”, Advances in Public Interest Accounting, Vol. 8, pp. 121-155.

Gibson, R., Nixon, P. and Ward, S. (eds.) (2003) Political Parties and the Internet: Net Again? New York: Routledge.

Graham, P., Keenan, T. and Dowd, A-M (2004) "A Call to Arms at the End of History: A Discourse-Historical Analysis of George W. Bush's Declaration of War on Terror”, Discourse \& Society, Vol.15, pp. 199-221.

Habermas, J. (1989) Structural Transformation of the Public Sphere, Cambridge, Mass.: MIT Press.

Habermas, J. (1977) Erkenntnis und Interesse. Frankfurt: Suhrkamp.

Hall, S. and du Gay, P. (1996) Questions of Cultural Identity, London: Sage. 
Harris, P. (2003), "Machiavellian marketing: justifying ends and means in the modern politics", In: The Chartered Institute of Marketing Conference, Sydney, Australia, p. 21. (Unpublished)

Harris, P. and Lock, A.R. (2002) "Sleaze or clear blue water: the evolution of corporate and pressure group representation at the major UK party conferences", Journal of Public Affairs, Vol. 2, No. 3, pp. 136-151.

Harris, P. (2001) "To Spin or not to Spin, that is the Question: the Emergence of Modern Political Marketing", The Marketing Review, Vol. 2, pp. 35-53.

Henneberg, S.C.M. and O'Shaughnessy, N.J. (2007) "Theory and concept development in political marketing: Issues and an agenda", in Henneberg, S.C.M. and O'Shaughnessy, N.J. (eds.), Journal of Political Marketing, Vol. 6, Nos. 2/3, pp. 5-31.

Henneberg, S.C. M. (2004) "The views of an advocatus dei: Political marketing and its critics", Journal of Public Affairs, Vol. 4 Issue 3, pp. 225-243.

Henneberg, S.C. M. (2002) “Understanding Political Marketing”, in O’Shaughnessy, N.J. and Henneberg, S.C.M. (eds.) The Idea of Political Marketing, Westport,Conn., London: Praeger, pp. 93-170.

Hirschman, E.C. and Holbrook, M.B. (1982) "Hedonic Consumption: Concepts, Methods and Propositions", Journal of Marketing 46, pp. 92-101. 
Holbrook, M. (1997) "Looking Back on looking backward: a retrospective review of Edward Bellamy's macromarketing classic”, Journal of Macromarketing, Spring, pp. 145-151.

Horkheimer, M. and Adorno, T. (1948/1972) Dialectic of the Enlightenment, New York: Herder and Herder.

Hunt, S.D. (1983) “General Theories and the Fundamental Explananda of Marketing”, Journal of Marketing, Vol. 47, Fall, pp. 9-17.

Ingram, P. and Lees-Marshment, J.P.(2002) "The Anglicisation of political marketing: How Blair 'out-marketed' Clinton”, Journal of Public Affairs, Vol. 2, No. 2, pp. 44-57.

Jacobson, M.F. and Mazur, L.A. (1995) Marketing Madness: A Survival Guide for a Consumer Society. Boulder. Westview Press.

Jäger, S. (2001) "Discourse and Knowledge: Theoretical and Methodological Aspects of a Critical Discourse and Dispositive Analysis", Chapter 3, pp. 32-62, in Wodak, R, and Meyer, M. (eds), (2001), Methods of Critical Discourse Analysis. London: SAGE.

Kaid, L. L. (2004) "Political Advertising", in L. L. Kaid (ed.), Handbook of Political Communication Research, London: Routledge, pp. 155-202.

Kelley, S. (1956) Professional Public Relations and Political Power. Baltimore: John Hopkins. 
Kellner, D. (1989) Critical Theory, Marxism and Modernity. Cambridge and Baltimore: Polity and Johns Hopkins University Press.

Kellner, D. (1995) Media Culture, Cultural Studies, Identity and Politics Between the Modern and the Postmodern, London and New York: Routledge.

Kotler, P. (1975) "Overview of political candidate marketing”, Advances in Consumer Research, Vol.2, Issue 1, pp. 761-770

Kotler, P. and Andreassen, A. (1991) Strategic Marketing for Nonprofit Organizations (4 $4^{\text {th }}$ ed.). Englewood Cliffs, NJ.: Prentice Hall.

Kotler, P. and Kotler, N. (1999) "Political marketing. Generating effective candidates, campaigns and causes", in Newman, B, I. (eds), Handbook of Political Marketing. Thousand Oaks: Sage.

Kraus, S. (1999) ‘Televised Debates: Marketing Presidential Candidates', in Newman, B.I. (ed.), Handbook of Political Marketing. Thousand Oaks, CA: Sage Publications, pp.389-403.

Laclau. E. and Mouffe, C. (2001) Hegemony and Socialist Strategy: Towards a Radical Democratic Politics, $2^{\text {nd }}$ edn., New York: Verso.

Law, J. and Hassard, J. (1999) Actor Network Theory and After, Malden, MA: Blackwell.

Lees-Marshment, J. (2001b) Political Marketing and British Political Parties: The Party's just Begun. Manchester University Press: Manchester. 
Lees-Marshment, J. (2001a) The marriage of politics and marketing”, Political Studies, Vol. 49 Issue 4, pp. $692-713$

Lees-Marshment, J. (2002) "Marketing good works: New trends in how interest group recruit supporters”, Journal of Public Affairs, Vol.3, No. 4, pp. 358-370.

Leowenthal, L. (1961) Literature, Popular Culture and Society, Englewood Cliffs, NJ: PrenticeHall.

Lock, A. and Harris, P.(1996) "Political Marketing: Vive la différence", European Journal of Marketing, Vol.30, Nos. 10/11, pp.14-24.

Maarek, P. (1995) Political Marketing and Communication. London: John Libbey.

Marcuse, H. (1964) One-dimensional Man: Studies in the Ideology of Advanced Industrial Society, Boston: Beacon Press.

Martin-Rojo, L. and van Dijk, T.A. (1997) "There was a problem, and it was solved! Legitimating the expulsion of "illegal" immigrants in Spanish parliamentary discourse", Discourse and Society, Vol. 8, No. 4, pp. 523-567.

McClure, K. (1996) “The institutional subordination of contested issues: the case of Pittsburgh's stell workers and ministers", Communication Quarterly, 44/4, pp. 487-501. 
Meyer, M. (2001) "Between Theory, Method and Politics: Positioning of the Approaches to CDA", Chapter 2, in Wodak, R, and Meyer, M. (eds), (2001), Methods of Critical Discourse Analysis. London: Sage, pp. 14-31.

Morgan, G. (1992) "Marketing Discourse and Practice: Towards a Critical Analysis", in Alvesson, M. and Willmott, H. (eds.) (1992), Critical Management Studies. London: Sage, pp.136-158,

Moufahim, M., Humphreys, M., Mitussis, D., Fitchett, J. (2007) "Interpreting discourse: a critical discourse analysis of the marketing of an extreme right party", Journal of Marketing Management, Volume 23, No. 5/6, pp. 537-558

Narver, J. and Slater, S. (1990) "The Effect of Market Orientation on Business Profitability", Journal of Marketing, Vol. 54, pp. 20-35.

Newman, B.L. (1994) The Marketing of the President: Political Marketing as Campaign Strategy. London: Sage.

Niffenegger, P. (1989) "Strategies for success from political marketers", Journal of Consumer Marketing, Vol.6 No. 1, Winter, pp. 115-151.

O'Cass, A. (1996) "Political marketing and the marketing concept", European Journal of Marketing, Vol.30, No. 10/11, pp. 37-53 
O'Leary, R. and Iredale, I. (1976), “The Marketing Concept: Quo Vadis?”, European Journal of Marketing, Vol. 10, No. 3, pp. 146-158.

O’Shaughnessy, N. (2002) “Towards an Ethical Framework for Political Marketing”, Psychology \& Marketing, Vol. 19, No. 12, pp. 1079-1094.

O’Shaughnessy, N. (1996) "Social propaganda and social marketing: a critical difference", European Journal of Marketing, Vol.30, No.10/11, pp.54-67.

O’Shaughnessy, N. and Henneberg, S. (eds) (2007) Theory and Concept Development in Political Marketing, Journal of Political Marketing (2007), Vol. 6.

O’Shaughnessy, N.(2001) "The marketing of political marketing”, European Journal of Marketing, Vol.35, No. 9/10, pp. 1047-1057

O’Shaughnessy, N.(2003) “The Symbolic State: a British Experience”, Journal of Public Affairs, Vol. 3, No. 4, pp. 297-312.

Phillips, N. and Hardy, C. (2002) Discourse Analysis. Investigating Processes of Social Construction. Thousand Oaks, CA: Sage Publications.

Richardson, J. (2008) “'Our England': Discourses of 'Race' and Class in Party Election Leaflets", Social Semiotics, Vol. 18, No. 3, pp. 321-335.

Roper, J. (2005) “Organisational identities, idenitification and positioning: learning from political 
fields", Public Relations Review, Vol. 31, pp. 139-148.

Sabato, L. (1981) The Rise of Political Consultants: New Ways of Winning Elections. New York: Basic Books.

Savigny, H. (2008), The Problem of Political Marketing. London: The Continuum International Publishing group.

Savigny, H. (2004), “Political Marketing: a Rational Choice?”, Journal of Political Marketing, Vol. 3, No. 1, pp. 21-38.

Scammell, M. (1995), Designer Politics: How Elections are Won. London: Macmillan.

Scammell, M. (1996), "The Odd Couple: Marketing and Maggie”, European Journal of Marketing, Vol. 30, No. 10/11, pp.122-135.

Scammell, M. (1999), "Political Marketing: Lessons for Political Science”, Political Studies, XLVII, pp. 718-739

Schneider, H. (2004), "Branding in politics — manifestations, relevance and identity —oriented management, Journal of Political Marketing, Vol. 3, pp. 41-67.

Schön, D.A. and Rein, M. (eds) (1994), Frame Reflection: Toward the Resolution of Intractable Policy Controversies. New York: Basic Books. 
Schroeder, J. E. (2007), “Critical marketing: insights for informed research and teaching”, in Saren, M. Maclaran, P., Goulding, C., Elliott, R. Shankar, A. and Catterall, M. (eds) 2007. Critical Marketing: Defining the Field. Oxford: Elsevier, pp. 18-29.

Shama, A. (1973), "Applications of the marketing concept to candidate marketing", in Proceedings of the Fourth Conference of the Association for Consumer Research, pp.793-801.

Tadajewski, M. and Brownlie, D. (2008)(Eds.), Critical Marketing: Issues in Contemporary Marketing, Chichester: John Wiley and Sons.

Teo, P. (2000), "Racism in the news: a Critical Discourse Analysis of News Reporting in Australian newspapers", Discourse \& Society, Vol. 11, No. 1, pp. 7-49.

Titscher, S., Meyer, M., Wodak, R. and Vetter, E. (2000), Methods of Text and Discourse Analysis. London: Sage.

Van Leeuwen, T. (1993), "Genre and field in Critical Discourse Analysis", Discourse and Society, Vol. 4, No. 2, pp. 193-223.

Vargo, S.L. and Lusch, R.F. (2004) "Evolving to a New Dominant Logic for Marketing”, Journal of Marketing, Vol. 68, No. 1, pp. 1-17.

Weaver, C. K., Motion, J., \& Roper, J. (2006). From propaganda to discourse (and back again): Truth, power and public relations. In J. L'Etang \& M. Pieczka (Eds.), Critical Perspectives in Public Relations (2nd ed., pp. 7-22). London and Boston: International Thomson Business Press. 
Weaver, C.K., Motion, J., and Roper, J. (2004) “Truth, Power and Public Interest: a theoretical theorising of propaganda and public relations", International Communication Conference, New Orleans, May 27-31.

Wodak, R. (2001), “The Discourse-Historical Approach”, Chapter, in Wodak, R. and Meyer, M. (2001), Methods of Critical Discourse Analysis, London: Sage, pp.63-94.

Wodak, R., de Cillia, R., Reisigl, M. and Liebhart, K. (1999). The Discursive Construction of National Identity, Edinburgh: EUP.

Wring, D. (1996), "Political Marketing and Party Development in Britain: A "Secret" History", European Journal of Marketing, Vol.30, No. 10/11, pp.100-113

Wring, D. (2002), "Images of Labour: the progression and politics of party campaigning in Britain”, Journal of Political Marketing, Vol. 1, No. 1, pp. 23-37.

Wring, D. (2001), "Labouring the point: operation victory and the battle for a second term", Journal of Marketing Management, Vol. 17, pp. 913-927.

Wring, D and Savigny, H. (2008), “An Ideology of Disconnection: For a Critical Political Marketing", $5^{\text {th }}$ International Conference on Political Marketing, Manchester. 